\title{
Pengaruh Intellectual Capital Terhadap Kinerja Keuangan dan Nilai Perusahaan
}

(Studi Pada Perusahaan Makanan dan Minuman Yang Terdaftar di BEI)

\author{
Petrus Gani \\ Universitas IBBI \\ petrusgani.ibbi@gmail.com
}

*Corresponding Author

$\begin{array}{ll}\text { Diajukan } & : \text { 24 Desember } 2021 \\ \text { Disetujui } & : 31 \text { Desember } 2021 \\ \text { Dipublikasi } & : \text { 2 Januari } 2022\end{array}$

\begin{abstract}
This study has objectives to analyze the influence of intellectual capital on financial performance and company value, and also examined the influence of financial performance as an intervening variable on company value. The population of the research is the manufacturing of sub-food and beverage industries listed in 2015-2019 consisted of 20 companies. This study has 12 companies as sample that chosen based on the purposive sampling method. Partial Least Square (PLS) as alternative of SEM and as data analysis technique using SmartPLS 3.3 application. The results of this study indicate that partially VAHU and STVA have a significant positive effect on financial performance. Meanwhile, VACA has no significant positive effect on financial performance. Simultaneously VAHU, STVA, and VACA have significant positive effect on financial performance. On the other side partially and simultaneously VAHU, STVA, and VACA have no directly significant positive effect on company value. But through financial performance.
\end{abstract}

Keywords: Company Value; Financial Performance; STVA; VACA; VAHU; and VACA

\section{PENDAHULUAN}

Perkembangan informasi yang pesat saat ini telah menjadi prioritas yang diterapkan perusahaan dimana informasi tersebut terdiri dari beberapa faktor seperti faktor pengetahuan, teknologi informasi, dan intellectual capital (Ozkan et al. 2016). Teknologi informasi telah menciptakan sistem perekonomian yang baru dimana pengolahan informasi, pengkajian ilmu, pengetahuan dan teknologi sudah menjadi komoditas utama produktivitas sebuah perusahaan. Fanomena ini menjadi faktor penyebab banyaknya perusahaan saat ini yang mengubah pola dan strategi bisnisnya dari pola manajemen berbasis tenaga kerja (labour based business) menjadi manajemen berbasis pengatahuan (knowledge based business) sebagai cara untuk memaksimalkan kinerja keuangan dan meningkatkan nilai perusahaan.

Memaksimalkan kinerja keuangan merupakan visi jangka panjang perusahaan baik yang belum menawarkan saham ke publik maupun perusahaan yang belum. Karena berdasarkan analisis yang dilakukan oleh setiap manajemen terhadap kinerja keuangan yang mereka miliki akan menunjukkan bagaimana prospek perusahaaan tersebut di masa yang akan datang. Dan hal ini akan menarik perhatian para pemangku kepentingan dalam menjalin kerja sama dengan perusahaan tersebut.

Meningkatkan nilai perusahaan juga merupakan salah satu visi jangka panjang yang perlu dicapai oleh setiap perusahaan, khususnya perusahaan yang telah menawarkan sahamnya ke publik. Meningkatkan nilai perusahaan sangat mempengaruhi keberlangsungan perusahaan di masa yang akan datang dalam menghadapi persaingan global (global competitive). Hartati (2014), menyebutkan bahwa suatu perusahaan dapat dikatakan kompetitif apabila dapat menciptakan nilai ekonomis yang lebih tinggi dibandingkan perusahaan lain dalam sektor yang sama.

Aset berbasis pengetahuan merupakan salah satu komponen esensial bisnis dan sumber daya yang dinilai dapat memperoleh dan mempertahankan competitive advantage perusahaan secara 
berkelanjutan. Intellectual capital (IC) merupakan salah satu bagian dari aset tidak berwujud yang berbasis pengetahuan yang dapat diarahkan ke dalam suatu proyek untuk menciptakan nilai lebih dan keunggulan suatu perusahaan (Habiburrachman, 2008). Akan tetapi pengukuran yang tepat belum dapat ditetapkan dalam PSAK dikarenakan belum ada ketentuan secara rinci mengenai intellectual capital. Hal ini menyebabkan terbatasnya informasi mengenai nilai aset yang belum dicatat sesuai dengan keadaan perusahaan sebenarnya. Keterbatasan tersebut memungkinkan adanya kesenjangan informasi dalam laporan keuangan terkait nilai perusahaan dan mengakibatkan informasi mengenai kinerja keuangan kurang memadai untuk digunakan dalam pengambilan keputusan.

Terbatasnya ketentuan standar akuntansi mengenai IC mendorong para ahli untuk membuat model pengukuran dan pelaporan IC. Menurut Bontis (1998), menyebutkan bahwa intellectual capital terdiri dari 3 bagian, yaitu human capital (HC), structural capital (SC), dan customer capital (CC). Penelitian ini menggunakan salah satu model yang sangat populer di berbagai negara yaitu Value Added Intellectual Coeficient $\left(\mathrm{VAIC}^{\mathrm{TM}}\right.$ ) yang dikemukakan oleh Pulic (1998). VAIC $^{\mathrm{TM}}$ tidak digunakan untuk mengukur IC, melainkan dampak dari pengelolaan IC (Ulum, 2017).

Ulum (2017), mencatat bahwa Intellectual Capital dapat diasumsikan sebagai bagian penting dalam suatu korporasi yang ditandai dengan perubahan fokus manajemen dari modal fisik ke modal tidak berwujud ketika mempertimbangkan proses 'penciptaan nilai' yang kemudian berkembang menjadi kesadaran akan pentingnya pelaporan IC dalam laporan keuangan.

Dari beberapa peneliti terdahulu, penelitian ini dilakukan dengan mengacu pada penelitian Loi (2019) yang meneliti pengaruh intellectual capital terhadap nilai pasar dan kinerja keuangan perusahaan manufaktur yang terdaftar di BEI tahun 2012-2017 dengan menggunakan metode VAIC yang dikemukakan oleh Pulic (1998). Yang membedakan penelitian ini dengan penelitian tersebut di atas adalah data sampel sektor perusahaan yang digunakan sesuai dengan tahun penelitiannya. Peneliti mengambil data sampel perusahaan sub sektor konsumsi makanan dan minuman yang terdaftar di Bursa Efek Indonesia tahun 2015-2019, karena Industri dibidang makanan dan minuman mempunyai strategis yang tepat dan dapat menciptakan inovasi produk yang dapat meningkatkan volume penjualan dan keuntungan walaupun ditengah tingkat persaingan dan krisis keuangan global, tetapi perusahaan makanan dan minuman dapat terus bersaing, disamping itu perusahaan makanan dan minuman yang telah dikembangkan dapat berinovasi untuk menciptakan suatu produk makanan dan minuman yang terbaru, yang lebih bervariasi dengan menciptakan suatu produk yang belum ada sehingga dapat meningkatkan konsumen serta peluang untuk menanamkan investasi pada sektor makanan dan minuman sangat menjanjikan dengan tingkat pemasaran yang luas. Dalam penelitian Loi (2019), kinerja keuangan digunakan sebagai variabel moderasi, sedangkan dalam penelitian ini digunakan sebagai variabel terikat sekaligus variabel intervening yang akan dikaji. Selain itu indikator yang digunakan untuk variabel dependen kedua dalam penelitian ini adalah Tobin's Q.

\section{Resource-Bases Theory (RBT)}

Menurut Ulum (2017 : 23), teori RBT menyatakan bahwa perusahaan memiliki sumber daya (resources) yang dapat membantu perusahaan memiliki keunggulan bersaing dan mengarahkan perusahaan untuk memiliki kinerja jangka panjang yang baik apabila dikelola dengan baik. Sumber daya tersebut dinilai memiliki nilai jual yang cukup tinggi, unik, dan dapat diarahkan untuk menciptakan keunggulan bersaing. Salah satunya adalah intellectual capital yaitu sumber daya yang dinilai memiliki sifat bernilai (valuable), mampu bertahan lama dan tidak mudah ditiru (inimitable), jarang ditemui (rare), tidak dapat ditransfer atau digantikan (non-subtitutable).

\section{Signaling Theory (Teori Pensinyalan)}

Signaling theory menjelaskan pentingnya informasi perusahaan bagi keputusan investasi pihak eksternal. Pengungkapan informasi secara lengkap dan mencakup keseluruhan dapat menunjukkan kinerja perusahaan pada masa lampau dan prospek kinerja perusahaan pada masa yang akan datang. Dengan memberikan informasi yang sesuai dengan sebagaimana mestinya 
(relevan), lengkap, akurat (didukung oleh data yang valid), dan tepat waktu akan sangat bermanfaat bagi pengambilan keputusan investasi oleh investor dan pengevaluasian nilai perusahaan oleh pasar (Brigham \& Joel, 2001).

\section{Stakeholder Theory (Teori Stakeholder)}

Teori stakeholder lebih memperhatikan kedudukan para stakeholder yang diperkirakan lebih kuat daripada hanya kedudukan shareholder saja. Tujuan utama dari teori stakeholder adalah untuk membantu efektif itas pengelolaan sumber daya melalui manajemen perusahaan dengan mengusahakan penciptaan nilai sebagai efeknya, baik dari aktivitas-aktivitas yang mereka lakukan dan meminimalkan resiko kerugian yang dianggap mungkin muncul bagi stakeholder mereka (Chariri \& Imam, 2007). Penciptaan nilai dalam hal ini berhubungan dengan pemanfaatan seluruh kemampuan yang berada di perusahaan baik tenaga kerja (human capital), aset fisik (physical capital), maupun struktur organisasi (structural capital).

\section{Intellectual Capital (IC)}

Intellectual Capital adalah salah satu bagian aset tidak berwujud yang berupa sumber daya informasi dan pengetahuan yang bermanfaat dalam meningkatkan daya saing (competitive adventage) dan performa perusahaan. Ulum (2017) mengklasifikasikan intellectual capital menjadi tiga elemen yaitu human capital, structural/organizational capital dan relational/customer capital.

Human capital dapat dikatakan lifeblood dalam intellectual capital, karena memuat sumber inovasi dan tempat bersumbernya pengetahuan yang sangat berguna, keterampilan dan kompensasi dalam suatu organisasi atau perusahaan dalam menemukan solusi untuk menjawab masalah bisnis perusahaan tersebut.

Structural capital atau organizational capital merupakan abilitas suatu organisasi/perusahaan dalam memenuhi proses aktivitas perusahaan dan struktur sistemnya yang mendukung usaha karyawan untuk menghasilkan kinerja intelektual yang optimal dan kinerja bisnis secara keseluruhan.

Relational capital atau customer capital adalah nilai secara faktual merupakan hubungan yang harmonis (association network) yang dimiliki perusahaan dengan para mitranya.

\section{Value Added Intellectual Coefficient (VAIC ${ }^{T M}$ )}

$\mathrm{VAIC}^{\mathrm{TM}}$ merupakan salah satu metode pengukuran kinerja intellectual capital yang mudah karena hanya menggunakan data yang telah tersedia dalam laporan keuangan (financial statement). Metode ini dimulai dengan kemampuan perusahaan untuk menciptakan value added (VA). Pada prinsipnya, VAIC dipakai untuk mengukur seberapa kuantitas nilai baru yang dapat dihasilkan diciptakan oleh masing-masing elemen-elemen dalam sumber daya. Value added (VA) adalah indikator paling relevan untuk menilai prestasi bisnis dan memperlihatkan kemampuan perusahaan dalam penciptaan nilai yang merupakan selisih antara output dan input. Output (OUT) menjelaskan kembali revenue dan meliputi semua produk yang ditawarkan di pasar. Sedangkan input (IN) meliputi semua beban atau biaya yang dialokasikan untuk memperoleh revenue tersebut, kecuali beban tenaga kerja (labour expense). Hal ini disebabkan karena dalam model Pulic tenaga kerja diperlakukan sebagai entitas penciptaan nilai yang dipengaruhi oleh efisiensi dari komponen VAIC yaitu Value Added Human Capital (VAHU), Structural Capital Value Added (STVA), dan Value Added Capital Employee (VACA).

Value added (VA) dapat dihitung menggunakan rumus berikut:

$$
V A=O U T P U T-I N P U T
$$

Dimana:

Output : total penjualan dan penghasilan lain

Input : beban dan biaya-biaya (selain biaya karyawan)

Value Added Human Capital (VAHU) merupakan salah satu elemen IC yang berfungsi untuk 
mengindikasikan seberapa besar kuantitas VA yang dihasilkan melalui biaya /dana yang dikeluarkan perusahaan untuk karyawan. VAHU dapat dinyatakan dalam rumus berikut:

$$
V A H U=\frac{V A}{H C}
$$

Dimana:

VAHU : rasio dari VA terhadap HC

Value added (VA) : selisih antara output dan input

Structural Capital Value Added (STVA) merupakan instrumen IC yang berfungsi untuk menunjukkan kontribusi SC dalam menghasilkan value added. STVA mengukur seberapa banyak SC yang diperlukan untuk menghasilkan satu rupiah dari VA. STVA dapat dinyatakan dalam rumus berikut:

$$
S T V A=\frac{S C}{V A}
$$

\section{Dimana:}

Structural Capital (SC) : selisih antara VA dan HC

Value Added (VA) : selisih antara ouput dan input

Value Added Capital Employee (VACA) merupakan suatu indikator yang mengukur ikatan baik antara perusahaan dengan bisnis. Jika satu unit dari capital employee (CE) mampu memperoleh higher return dari perusahaan lain, maka hal itu menunjukkan perusahaan sangat baik dalam memaksimalkan CE yang dimilikinya. VACA dapat dinyatakan dalam rumus berikut:

$$
V A C A=\frac{V A}{C E}
$$

Dimana:

Capital Employed (CE) : dana yang tersedia (total ekuitas dan laba bersih)

Value Added (VA) : selisih antara ouput dan input

\section{Kinerja Keuangan}

Kinerja keuangan merupakan hasil atau prestasi yang telah dicapai manajemen dalam menjalankan tanggung jawabnya dalam mengalokasikan aset perusahaan secara efektif selama periode waktu tertentu. Dalam Khairiah (2016) abilitas keuangan perusahaan dibutuhkan untuk menetapkan dan menilai tingkat keberhasilan perusahaan atas dasar aktivitas finansial yang dilakukan. Penelitian ini melakukan pengukuran terhadap kinerja keuangan dengan menggunakan rasio ROA (Return On Asset), ROE (Return On Equity), dan GR (Growth Revenue).

Return On Asset (ROA) merupakan rasio keuangan untuk melihat besar persentase laba yang dihasilkan sebuah perusahaan sehubungan dengan sumber daya keseluruhan dalam hal pengembalian aset. ROA dapat dihitung menggunakan rumus berikut:

$$
R O A=\frac{(\text { Earning After Tax })}{(\text { Total Assets })}
$$

Dimana:

Earning After Tax (EAT) : laba bersih setelah pajak

Total Assets

$$
\text { : total kekayaan yang dimiliki suatu entitas }
$$

Return On Equity (ROE) merupakan rasio keuangan untuk melihat besar persentase laba yang dihasilkan sebuah perusahaan sehubungan dengan sumber daya keseluruhan dalam hal pengembalian ekuitas. ROE dapat dihitung menggunakan rumus berikut: 


$$
R O E=\frac{(\text { Earning After Tax })}{(\text { Total Equity })}
$$

Dimana:

Earning After Tax (EAT) : laba bersih setelah pajak

Total Equity

: total ekuitas yang dimiliki suatu entitas

Growth Revenue (GR) merupakan rasio keuangan untuk melihat besar persentasi pertumbuhan laba dari periode sebelumnya terhadap periode berjalan yang cenderung mengalami peningkatan atau penurunan seiring waktu serta mengidentifikasi tren dalam bisnis. GR dapat dihitung menggunakan rumus berikut:

$$
G R=\frac{(\text { Current Year Revenue }- \text { Prior Year Revenue })}{(\text { Prior Year Revenue })}
$$

\section{Dimana:}

Current Year Revenue (CYR) : akumulasi laba tahun berjalan

Prior Year Revenue (PYR) : : akumulasi laba periode sebelumya

\section{Nilai perusahaan (Tobin's Q)}

Nilai perusahaan adalah taksiran kualitas yang diperoleh dari pemangku kepentingan seperti investor, kreditur, dan stakeholder lainnya terhadap kondisi perusahaan yang umumnya dikaitkan dengan harga saham perusahaan yang dapat digunakan sebagai acuan untuk menaksir harga keseluruhan aset perusahaan tersebut ketika dijual atau diakuisisi. Nilai perusahaan dalam penelitian ini menggunakan alat ukur Tobin's Q karena dapat memposisikan nilai perusahaan sebagai gambaran nilai aset berwujud dan aset tidak berwujud serta dapat mencerminkan tingkat efektifitas dan efisiensi sebuah perusahaan dalam mengalokasikan resource yang memuat aset perusahaan tersebut. Tobin's $Q$ dapat dihitung menggunakan rumus sebagai berikut:

$$
\text { Tobin's } Q=\frac{(\text { Kapitalisasi Pasar }+ \text { Total Liabilitas })}{(\text { Total Aset })}
$$

\section{Kerangka Pemikiran}

Stakeholder theory mengemukakan bahwa perusahaan tidak lagi menempatkan dirinya sebagai kedudukan tertinggi sehingga dengan pola hubungan seperti ini arah dan tujuan perusahaan bukan lagi pada bagaimana menghimpun kekayaan sebesar-besarnya, melainkan lebih mengarah kepada pencapaian pembangunan yang berkelanjutan (sustainability development).

Berdasarkan peneliti terdahulu Loi (2019) bahwa variabel yang diteliti secara terpisah diantaranya: human capital (VAHU), structural capital (STVA), dan capital employed (VACA) karena setiap variabel memiliki manfaat dan peran yang berbeda-beda namun dapat digabungkan secara keseluruhan untuk diteliti. Loi menyatakan bahwa pengelolaan terhadap intellectual capital (IC) sangat penting karena diyakini dapat memaksimalkan kinerja keuangan dan meningkatkan nilai perusahaan tertentu. Berdasarkan uraian teori dan penelitian sebelumnya, kerangka konseptual yang dikemukakan dalam penelitian ini sebagai berikut: 


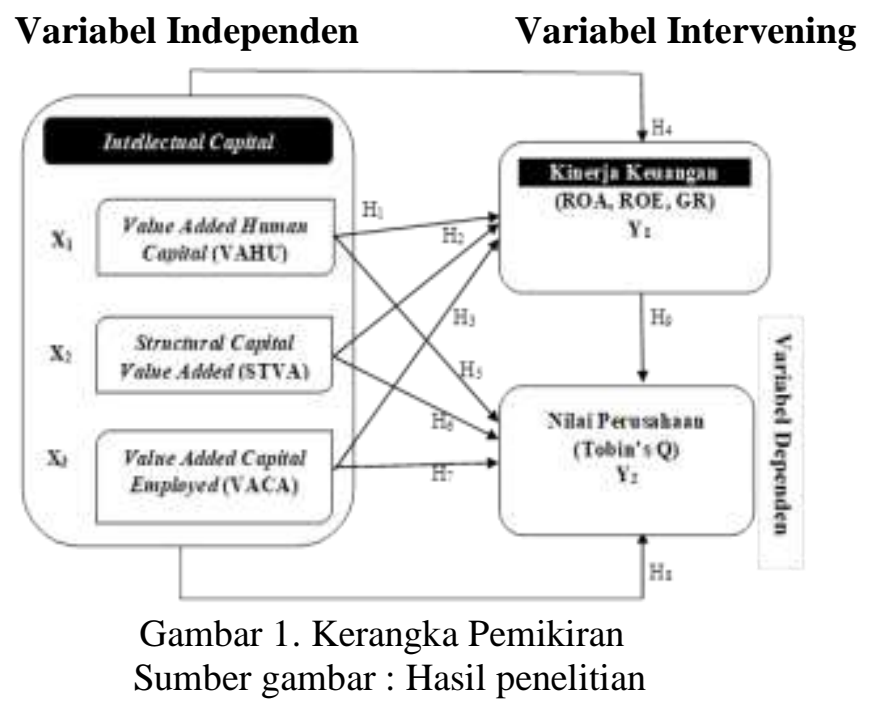

\section{Pengembangan Hipotesis}

Pengembangan hipotesis adalah suatu pengembangan dari kesimpulan atau jawaban sementara dari permasalahan penelitian yang akan dibuktikan dengan data empiris dan beberapa teori yang digunakan seperti: Resource-Bases Theory (RBT), Signaling Theory, Stakeholder Theory. Sehingga dari kerangka pemikiran yang telah dipaparkan diatas berikut ini dapat diajukan sebagian jawaban sementara terhadap permasalahan dalam penelitian ini.

Penelitian terhadap kinerja keuangan perusahaan dengan hasil penelitian yang mengindikasikan bahwa intellectual capital (IC) memiliki pengaruh signifikan terhadap kinerja keuangan (Agustiana, 2020). Hasil ini mendukung penelitian Pramelasari (2016) yang membuktikan bahwa intellectual capital berpengaruh positif signifikan terhadap kinerja keuangan perusahaan.

Berdasarkan uraian penelitian tersebut maka dapat dikembangkan hipotesis sebagai berikut:

H1 : Value Added Human Capital (VAHU) berpengaruh positif signifikan secara parsial terhadap kinerja keuangan perusahaan.

H2 : Structural Capital Value Added (STVA) berpengaruh positif signifikan secara parsial terhadap kinerja keuangan perusahaan.

H3 : Value Added Capital Employed (VACA) berpengaruh positif signifikan secara parsial terhadap kinerja keuangan perusahaan.

H4 : Value Added Human Capital (VAHU), Structural Capital Value Added (STVA), dan Value Added Capital Employed (VACA) berpengaruh positif signifikan secara simultan terhadap kinerja keuangan perusahaan.

Hasil penelitian Loi (2019) yang melakukan observasi pada perusahaan manufaktur di Bursa Efek Indonesia menunjukkan secara simultan variabel VAHU, STVA, dan VACA mempengaruhi nilai perusahaan. Hasil ini mendukung penelitian Jayanti (2017) yang menyatakan bahwa intellectual capital berpengaruh positif signifikan terhadap nilai perusahaan yang dikaitkan dengan nilai pasar yang diberikan oleh investor.

Berdasarkan uraian penelitian tersebut maka dapat dikembangkan hipotesis sebagai berikut:

H5 : Value Added Human Capital (VAHU)berpengaruh positif signifikan secara parsial terhadap nilai perusahaan.

H6 : Structural Capital Value Added (STVA) berpengaruh positif signifikan secara parsial terhadap nilai pasar perusahaan.

H7 : Value Added Capital Employed (VACA)berpengaruh positif signifikan secara parsial terhadap nilai pasar perusahaan. 
H8 : Value Added Human Capital (VAHU), Structural Capital Value Added (STVA), dan Value Added Capital Employed (VACA) berpengaruh positif signifikan secara simultan terhadap nilai pasar perusahaan.

Listiadi (2015) dalam penelitiannya menyatakan bahwa kinerja yang baik akan memberikan prospek nilai yang baik pula bagi para pengambil keputusan investasi. Berdasarkan uraian tersebut maka dapat dikembangkan hipotesis sebagai berikut:

H9 : Kinerja keuangan sebagai mediator berpengaruh positif signifikan terhadap nilai perusahaan.

\section{METODE}

Metode penelitian yang digunakan dalam penelitian ini adalah menggunakan teknik purposive sampling untuk seleksi sampelnya dan menggunakan Partial Least Square (PLS) untuk menganalisis datanya. Analisis Partial Least Square (PLS) merupakan salah satu teknik statistika multivariat yang memkomparasikan antara variabel independen berganda dan variabel dependen berganda dengan tujuan untuk memprediksi pengaruh variabel bebas dengan variabel terikat serta menunjukkan hubungan teoretis di antara kedua variabel (Abdillah \& Jogyanto, 2015:161). PLS merupakan analisis alternatif dari Structural Equation Model (SEM) untuk menangani masalah data yang terlalu kecil untuk diteliti menggunakan SEM dimana PLS dapat meneliti data yang berkisar lebih kecil dari 100 sampel. Dalam penelitian ini terdapat dua model pengukuran yakni outer model atau model pengukuran dan inner model atau model struktural.

Outer model atau model pengukuran merupakan bentuk penilaian terhadap validitas dan reliabilitas modelnya dengan melalui proses duplikasi algoritma, parameter model pengukuran (validitas konvergen, validitas diskriminan, composite reliability dan cronbach's alpha) didapatkan serta parameter ketepatan model prediksi (nilai $\mathrm{R}^{2}$ ). Rule of thumb secara umum digunakan untuk validitas konvergen adalah outer loading $>0.7$, communality $>0.5$, dan Average Variance Extracted (AVE) > 0.5 (Abdillah, 2015:195). Sedangkan rule of thumb secara umum digunakan untuk validitas diskriminan adalah akar AVE > korelasi variabel laten dan cross loading > 0.7 dalam sebuah variabel. Dalam uji reliabilitas konstruk rule of thumb nilai cronbach's alpha adalah >0.6dancomposite reliability adalah $>0.7$ yang artinya nilai yang berada dibawah 0.6 atau 0.7 konstruk tersebut belum reliabel.

Inner model atau model struktural merupakan bentuk evaluasi yang memiliki tujuan untuk mendefenisikan hubungan kausalitas antar semua variabel laten. Rule of thumbs yang digunakan untuk dugaan hasil PLS berdasarkan nilai skor loading pada tiap path antara konstruk laten dengan indikatornya $\geq 0,7$. Selain itu untuk nilai $\mathrm{R} 2$ atau varian pada variabel terikat adalah $\geq$ 0,10 (Abdillah \& Sugiyanto, 2015:185).

Dalam menguji hipotesis menggunakan SmartPLS, kriteria yang digunakan dalam pengambilan keputusan dari hasil uji bootstrapping adalah:

- Ha diterima jika nilai T-statistic > 1.96 pada untuk hipotesis dua arah (two tailed) pada tingkat signifikansi (alpha) 5\%.

- Ha ditolak jika nilai T-statistic < 1.96 pada untuk hipotesis dua arah (two tailed) pada tingkat signifikansi (alpha) 5\%.

\section{HASIL}

Penelitian ini memilih perusahaan sub sektor konsumsi makanan dan minuman yang terdaftar di Bursa Efek Indonesia periode 2015-2019 sebagai objek penelitian dimana perusahaan tersebut memiliki populasi sebesar 20 perusahaan. Melalui proses seleksi sampel yang dilakukan menggunakan beberapa kriteria maka diperoleh sebanyak 12 perusahaan yang layak untuk dijadikan sampel penelitian. Adapun seleksi sampel dapat dilihat dalam tabel berikut ini: 
Owner: Riset \& Jurnal Akuntansi

e-ISSN : 2548-9224 | p-ISSN : 2548-7507

Volume 6 Nomor 1, Januari 2022

DOI : https://doi.org/10.33395/owner.v6i1.613

Tabel 1. Pengambilan Sampel

\begin{tabular}{|c|l|c|}
\hline No & \multicolumn{1}{|c|}{ Keterangan } & Jumlah \\
\hline 1 & $\begin{array}{l}\text { Perusahaan makanan dan minuman yang terdaftar di BEI Periode 2015- } \\
2019 .\end{array}$ & 20 \\
\hline 2 & $\begin{array}{l}\text { Perusahaan makanan dan minuman yang tidak mempublikasikan } \\
\text { laporan tahunan secara berturut-turut periode 2015-2019. }\end{array}$ & (1) \\
\hline 3 & $\begin{array}{l}\text { Perusahaan makanan dan minuman yang mengalami kerugian pada } \\
\text { periode 2015-2019 }\end{array}$ & (7) \\
\hline & \multicolumn{1}{|c|}{ Jumlah Sampel } & 12 \\
\hline
\end{tabular}

Sumber tabel : Data sekunder yang diolah (2021)

Berdasarkan analisis data dengan menggunakan SmartPLS (2021) maka di peroleh statistik deskriptif atas variabel independen komponen-komponen yang membentuk VAIC ${ }^{\mathrm{TM}}$ (VAHU, STVA, dan VACA), kinerja keuangan (ROA, ROE, dan GR) dan nilai perusahaan (Tobin's Q) periode 2015-2019 dapat dilihat pada tabel berikut:

Tabel 2. Statistik Deskriptif VAIC ${ }^{\mathrm{TM}}$, Kinerja Keuangan dan Nilai Perusahaan

\begin{tabular}{|c|l|c|c|c|c|c|c|}
\hline No & Indikator & Missing & Mean & Median & Min & Max & Std.Dev \\
\hline 1 & VAHU & 5.534 & 3.971 & 3.971 & 1.006 & 22.960 & 5.050 \\
\hline 2 & STVA & 0.634 & 0.732 & 0.732 & 0.006 & 0.956 & 0.263 \\
\hline 3 & VACA & 1.655 & 0.567 & 0.567 & 0.061 & 13.534 & 2.267 \\
\hline 4 & ROA & 0.126 & 0.105 & 0.105 & 0.000 & 0.527 & 0.106 \\
\hline 5 & ROE & 0.241 & 0.183 & 0.183 & 0.001 & 1.241 & 0.265 \\
\hline 6 & GR & 0.191 & 0.174 & 0.174 & -0.940 & 1.091 & 0.360 \\
\hline 7 & TOBIN'S Q & 3.028 & 2.131 & 2.131 & 0.672 & 12.355 & 2.978 \\
\hline
\end{tabular}

Sumber tabel : Data sekunder yang diolah (2021)

Kemudian, pengujian hipotesis secara parsial mengenai pengaruh elemen-elemen value added intellectual capital terhadap kinerja keuangan hasilnya dapat dilihat pada tabel berikut:

Tabel 3. Pengaruh Parsial VAHU, STVA dan VACA Terhadap Kinerja Keuangan

\begin{tabular}{|c|c|c|r|c|c|}
\hline \multicolumn{1}{|l|}{ Path Coefficient } \\
\hline Indikator & Or.Sample & Sample Mean & Std.Dev & T-Statistics & P-Values \\
\hline VAHU $\rightarrow$ Kin. Keu & 0,512 & 0,504 & 0.126 & 4,062 & 0,000 \\
\hline STVA $\rightarrow$ Kin. Keu & 0,497 & 0,517 & 0,085 & 5,883 & 0,000 \\
\hline VACA $\rightarrow$ Kin. Keu & $-0,164$ & $-0,156$ & 0,107 & $\mathbf{1 , 5 2 4}$ & $\mathbf{0 , 1 2 8}$ \\
\hline
\end{tabular}

Sumber tabel : Hasil olah data SmartPLS (2021)

Berdasarkan hasil uji hipotesis menggunakan bootstrapping maka hasil uji pengaruh VAHU, STVA, dan VACA secara simultan dapat dilihat pada tabel berikut.

Tabel 4. Pengaruh Simultan VAHU, STVA dan VACA Terhadap Kinerja Keuangan

\begin{tabular}{|l|c|c|c|c|c|}
\hline \multicolumn{1}{|l|}{ Path Cofficient } \\
\hline Indikator & Or.Sample & Sample Mean & Std. Dev & T-Statistics & P-Values \\
\hline VAIC $\rightarrow$ Kin. Keu & 0.549 & 0.568 & 0.089 & 6.165 & 0.000 \\
\hline
\end{tabular}

Sumber tabel : Hasil olah data SmartPLS (2021)

Untuk hasil uji hipotesis menggunakan bootstrapping maka hasil uji pengaruh VAHU, STVA, dan VACA terhadap nilai perusahaan secara simultan dapat dilihat pada tabel berikut. 
DOI : https://doi.org/10.33395/owner.v6i1.613

Tabel 5. Pengaruh Parsial VAHU, STVA dan VACA Terhadap Nilai Perusahaan

\begin{tabular}{|c|c|c|c|c|c|}
\hline \multicolumn{7}{|l|}{ Path Coefficient } \\
\hline Indikator & Or. Sample & Sample Mean & Std. Dev & T-Statistics & P-Values \\
\hline VAHU $\rightarrow$ Nilai P & 0,217 & 0,23 & 0,141 & $\mathbf{1 , 5 4 2}$ & $\mathbf{0 , 1 2 4}$ \\
\hline STVA $\rightarrow$ Nilai P & 0,087 & 0,087 & 0,122 & $\mathbf{0 , 7 0 9}$ & $\mathbf{0 , 4 7 9}$ \\
\hline VACA $\rightarrow$ Nilai P & $-0,084$ & $-0,093$ & 0,066 & $\mathbf{1 , 2 6 3}$ & $\mathbf{0 , 2 0 7}$ \\
\hline
\end{tabular}

Sumber tabel : Hasil olah data SmartPLS (2021)

Hasil uji hipotesis menggunakan bootstrapping untuk uji pengaruh VAHU, STVA dan VACA secara simultan dapat dilihat pada tabel berikut.

Tabel 6. Pengaruh Simultan VAHU, STVA dan VACA Terhadap Nilai Perusahaan

\begin{tabular}{|c|c|c|c|c|c|}
\hline Path Cofficient \\
\hline Indikator & Or.Sample & Sample Mean & Std. Dev & T-Statistics & P-Values \\
\hline VAIC $\rightarrow$ Nilai P & 0,206 & 0,202 & 0,146 & $\mathbf{1 , 4 1 2}$ & $\mathbf{0 , 5 1 9}$ \\
\hline
\end{tabular}

Sumber tabel : Hasil olah data SmartPLS (2021)

\section{PEMBAHASAN}

Berdasarkan hasil analisis statistik deskriptif pada Tabel 2 maka dapat diketahui bahwa nilai minimum VAHU adalah 1,006 sedangkan nilai maksimum VAHU adalah 22,960 dan nilai ratarata (mean) VAHU adalah 5,534 dan standar deviasi VAHU adalah 5,050. Hal ini menunjukkan VAHU yang baik di sektor konsumsi makanan dan minuman karena memiliki nilai rata-rata dan standar deviasi yang cukup tinggi. Artinya HC (human capital) perusahaan berpotensi baik dalam menciptakan nilai tambah bagi perusahaaan.

Variabel STVA memiliki nilai minimum 0,006 sedangkan nilai maksimumnya adalah 0,956 dan nilai rata-rata (mean) STVA yang diperoleh adalah 0,634 dan standar deviasinya adalah 0,263 . Hal ini menujukkan bahwa STVA perusahaan sektor konsumsi makanan dan minuman belum cukup baik dalam menghasilkan nilai bagi perusahaan jika dilihat dari nilai rata-rata yang relatif rendah. Artinya perusahaan sektor konsumsi makanan dan minuman belum begitu memperhatikan pentingnya structural capital bagi perusahaan tersebut.

Nilai minimum variabel VACA adalah 0,061 sedangkan nilai maksimum variabel VACA adalah 13,534 dan nilai rata-rata (mean) variabel VACA adalah 1,655 dengan standar deviasi 2,267 . Hal ini menunjukkan VACA yang cukup baik bagi perusahaan sektor konsumi makanan dan minuman dalam menciptakan nilai tambah bagi perusahaan.

Untuk kinerja keuangan yang diproksikan dengan ROA memiliki nilai minimum 0,0005 sedangkan nilai maksimumnya adalah 0,527 dan nilai rata-rata (mean) variabel ROA adalah 0,126 dengan standar deviasi 0,106. Hal ini menunjukkan bahwa perusahaan sektor konsumsi makanan dan minuman berpotensi baik dalam mengembalikkan aset yang telah dialokasikan dengan baik oleh perusahaan-perusahaan tersebut.

Variabel laten kinerja keuangan yang diproksikan dengan ROE memiliki nilai minimum 0,001 sedangkan nilai maksimum variabel $\mathrm{ROE}$ adalah 1,241 dan nilai rata-rata (mean) dari variabel ROE adalah 0,241 dengan standar deviasi 0,265. Hal ini menunjukkan perusahaan sektor konsumsi makanan dan minuman yang sangat baik dalam mengembalikan modal yang telah dialokasikan dengan baik juga oleh perusahaan tersebut.

Kinerja keuangan yang diproksikan dengan variabel indikator GR memiliki nilai minimum 0,940 sedangkan untuk nilai maksimum variabel GR adalah 1,091 dan nilai rata-rata variabel GR adalah 0,191 dengan standar deviasi 0,360. Hal ini menunjukkan bahwa sebagian besar perusahaan sektor makanan dan minuman mengalami pertumbuhan laba yang cukup baik dalam setiap periodenya.

Diketahui bahwa nilai minimum dari nilai perusahaan yang diproksikan dalam variabel Tobin's Q adalah 0,672 sedangkan nilai maksimum nilai perusahaan yang diproksikan oleh Tobin's $Q$ adalah 12,355 dan nilai rata-rata (mean) dari nilai perusahaan jika diukur menggunakan Tobin's Q adalah 3,028 dan nilai standar deviasi Tobin's Q adalah 2,978. Hal ini menunjukkan sebagian besar nilai perusahaan yang cukup baik bagi perusahaan sektor konsumsi 
makanan dan minuman. Artinya investor memiliki kepercayaan yang baik terhadap perusahaan sektor konsumsi makanan dan minuman karena dianggap memiliki kemampuan untuk menghasilkan earning saham yang baik jika dilihat dari data kinerja keuangan yang diperoleh.

Lalu, dari hasil analisis data dengan SmartPLS (2021) terlihat hasil kinerja keuangan yang disajikan pada Tabel 3 dapat diketahui bahwa VAHU memiliki pengaruh positif signifikan secara parsial terhadap kinerja keuangan karena jika dilihat dari nilai T-Statistics sebesar 4,062 > 1,96 dan signifikansi P-Values $0,000<0,05$. Berdasarkan hasil pengujian dengan menggunakan bootstrapping yang menunjukkan nilai T-Statistics VAHU4,062 > 1,96, maka H1 diterima. Dan pengaruh ini dinyatakan signifikan karena nilai $P$-Values $0,000<$ alpha 0,05 . Artinya VAHU berpengaruh positif dan signifikan terhadap kinerja keuangan dimana setiap kenaikan nilai tambah yang dihasilkan oleh human capital perusahaan makanan dan minuman akan menaikkan juga kinerja keuangan dari perusahaan tersebut.

Tabel tersebut juga menunjukkan bahwa STVA memiliki pengaruh positif signifikan secara parsial terhadap kinerja keuangan jika dilihat dari nilai T-Statistics sebesar 5,8883 > 1,96 dan signifikansi P-Values $0,000<0,05$. Berdasarkan hasil pengujian dengan menggunakan bootstrapping yang menunjukkan nilai T-Statistics STVA 5,883>1,96, maka H2 diterima. Dan pengaruh ini dinyatakan signifikan karena nilai $P$-Values $0,000<$ alpha 0,05 . Artinya STVA berpengaruh positif dan signifikan terhadap kinerja keuangan dimana setiap kenaikan nilai tambah yang dihasilkan dengan adanya structural capital perusahaan makanan dan minuman akan menaikkan juga kinerja keuangan dari perusahaan tersebut.

Dapat juga diketahui bahwa VACA tidak memiliki pengaruh signifikan secara parsial terhadap kinerja keuangan jika dilihat dari nilai T-Statistics sebesar 1,524 $<1,96$ dan dan signifikansi P-Values $0.128>0.05$. Berdasarkan hasil pengujian dengan menggunakan bootstrapping yang menunjukkan nilai T-Statistics VACA 1,528 > 1,96, maka H3 ditolak. Dan pengaruh ini dinyatakan tidak signifikan karena nilai P-Values $0,128>$ alpha 0,05 . Artinya VACA tidak berpengaruh signifikan terhadap kinerja keuangan dimana setiap kenaikan nilai tambah yang dihasilkan oleh relational capital perusahaan makanan dan minuman tidak menaikkan kinerja keuangan dari perusahaan tersebut.

Dari hasil analisis data dengan SmartPLS (2021) terlihat pada Tabel 4 dapat diketahui bahwa secara simultan VAHU, STVA, dan VACA yang dirangkum dalam VAIC memiliki nilai TStatistics 6,165 > 1,96 dan P-Values $0.000<0.05$. Artinya secara simultan VAHU, STVA, dan VACA memiliki pengaruh positif dan signifikan terhadap kinerja keuangan.

Berdasarkan hasil pengujian dengan menggunakan bootstrapping yang menunjukkan nilai $T$ Statistics VAIC 6,165>1,96, maka H4 diterima. Dan pengaruh ini dinyatakan signifikan karena nilai $P$-Values $0,000>$ alpha 0,05 . Artinya VAIC berpengaruh positif dan signifikan terhadap kinerja keuangan dimana setiap kenaikan nilai tambah yang dihasilkan oleh setiap elemen-elemen intellectual capital perusahaan makanan dan minuman akan menaikkan juga kinerja keuangan dari perusahaan tersebut.

Dari hasil analisis data dengan SmartPLS (2021) terlihat pada Tabel 5 yang diketahui bahwa VAHU memiliki nilai T-Statistics 1,542 < 1.96 dan signifikansi P-Values 0,124 > 0,05. Artinya VAHU tidak memiliki pengaruh signifikan terhadap nilai perusahaan jika diuji secara langsung.Berdasarkan hasil pengujian dengan menggunakan bootstrapping yang menunjukkan nilai $T$-Statistics VAHU $1,542<1,96$, maka H5 ditolak. Dan pengaruh ini dinyatakan tidak signifikan karena nilai $P$-Values $0,124>$ alpha 0,05 . Artinya VAHU tidak berpengaruh signifikan terhadap nilai perusahaan dimana setiap kenaikan nilai tambah yang dihasilkan oleh human capital perusahaan makanan dan minuman tidak akan menaikkan juga nilai perusahaan dari perusahaan tersebut.

Juga dapat diketahui bahwa STVA memiliki nilai T-Statistics $0,709<1.96$ dan signifikansi P-Values $0,479>0,05$. Artinya STVA tidak memiliki pengaruh signifikan terhadap nilai perusahaan jika diuji secara langsung. Berdasarkan hasil pengujian dengan menggunakan bootstrapping yang menunjukkan nilai T-Statistics VAHU0,709 < 1,96, maka H6 ditolak. Dan pengaruh ini dinyatakan tidak signifikan karena nilai $P$-Values $0,479>$ alpha 0,05 . Artinya STVA tidak berpengaruh signifikan terhadap nilai perusahaan dimana setiap kenaikan nilai tambah yang dihasilkan melalui dukungan structural capital terhadap human capital pada perusahaan makanan 
dan minuman tidak akan menaikkan juga nilai perusahaan dari perusahaan tersebut.

Hasil dalam tabel tersebut menunjukkan bahwa VACA memiliki nilai T-Statistics 1,263 < 1.96 dan signifikansi P-Values 1,207 > 0,05. Artinya VACA tidak memiliki pengaruh signifikan terhadap nilai perusahaan jika diuji secara langsung.Berdasarkan hasil pengujian dengan menggunakan bootstrapping yang menunjukkan nilai T-Statistics VACA 1,263 < 1,96, maka H7 ditolak. Dan pengaruh ini dinyatakan tidak signifikan karena nilai $P$-Values $1,207>$ alpha 0,05 . Artinya VACA tidak berpengaruh signifikan terhadap nilai perusahaan dimana setiap kenaikan nilai tambah yang dihasilkan oleh relational capital pada perusahaan makanan dan minuman tidak akan menaikkan juga nilai perusahaan dari perusahaan tersebut. Dalam penelitian ini investor lebih mempertimbangkan hal-hal yang bersifat fisik seperti pertumbuhan laba dan kemampuan perusahaan dalam mengembalikan aset mereka dibandingkan dengan hal-hal yang tidak dapat dinyatakan dalam wujud moneter yang benefitnya dapat dilihat secara nyata.

Dari hasil analisis data dengan SmartPLS (2021) terlihat pada Tabel 6 yang menunjukkan bahwa VAHU, STVA dan VACA memiliki nilai T-Statistics $1,412<1.96$ dan signifikansi PValues 0,519>0,05. Artinya VAIC tidak memiliki pengaruh signifikan terhadap nilai perusahaan jika diuji secara langsung.Berdasarkan hasil pengujian dengan menggunakan bootstrapping yang menunjukkan nilai T-Statistics VAHU $1,412<1,96$, maka H8 ditolak. Dan pengaruh ini dinyatakan tidak signifikan karena nilai $P$-Values $0,159>$ alpha 0,05. Artinya VAIC (VAHU, STVA, dan VACA) tidak berpengaruh positif dan tidak signifikan secara simultan terhadap nilai perusahaan dimana setiap kenaikan nilai tambah yang dihasilkan oleh setiap elemen-elemen intellectual capital pada perusahaan makanan dan minuman tidak akan menaikkan nilai perusahaan tersebut.

\section{KESIMPULAN}

Berdasarkan hasil analisis data yang dilakukan menggunakan SmartPLS maka diperoleh beberapa kesimpulan sebagai berikut yakni, H1 diterima, karena secara parsial VAHU bernilai positif dan signifikan terhadap kinerja keuangan (ROA, ROE, dan GR) yang artinya setiap peningkatan nilai tambah yang dihasilkan oleh human capital akan sangat mendorong pemaksimalan kinerja keuangan, H2 diterima, karena secara parsial STVA bernilai positif dan signifikan terhadap kinerja keuangan (ROA, ROE, dan GR) yang artinya setiap peningkatan nilai tambah yang dihasilkan oleh structual capital akan sangat mendorong pemaksimalan kinerja keuangan, $\mathrm{H} 3$ ditolak, karena secara parsial VACA bernilai negatif dan tidak signifikan terhadap kinerja keuangan (ROA, ROE, dan GR) yang artinya setiap peningkatan nilai tambah yang dihasilkan oleh capital employee tidak akan mendorong pemaksimalan kinerja keuangan, $\mathrm{H} 4$ diterima, karena secara simultan Value Added Intellectual Capital (VAHU, STVA, dan VACA) bernilai positif dan signifikan terhadap kinerja keuangan (ROA, ROE, dan GR) yang artinya setiap peningkatan nilai tambah yang dihasilkan oleh elemen-elemen intellectual capital akan sangat mendorong pemaksimalan kinerja keuangan, H5 ditolak, karena secara parsial VAHU bernilai negatif dan tidak signifikan terhadap nilai perusahaan (Tobin's Q) jika diuji secara langsung dan namun bernilai positif serta signifikan terhadap nilai perusahaan melalui mediator kinerja keuangan yang artinya setiap peningkatan nilai tambah yang dihasilkan oleh human capital tidak akan mendorong peningkatan nilai perusahaan secara langsung dan namun dapat mendorong peningkatan nilai perusahaan tersebut melalui peningkatan kinerja keuangan, H6 ditolak, karena secara parsial STVA bernilai negatif dan tidak signifikan terhadap nilai perusahaan (Tobin's Q) jika diuji secara langsung dan namun bernilai positif serta signifikan terhadap nilai perusahaan melalui mediator kinerja keuangan yang artinya setiap peningkatan nilai tambah yang dihasilkan oleh structural capital tidak akan mendorong peningkatan nilai perusahaan secara langsung dan namun dapat mendorong peningkatan nilai perusahaan tersebut melalui peningkatan kinerja keuangan, $\mathrm{H7}$ ditolak, karena secara parsial VACA bernilai negatif dan tidak signifikan terhadap nilai perusahaan (Tobin's Q) jika diuji secara langsung dan namun bernilai positif serta signifikan terhadap nilai perusahaan melalui mediator kinerja keuangan yang artinya setiap peningkatan nilai tambah yang dihasilkan oleh capital employee tidak akan mendorong peningkatan nilai perusahaan secara langsung dan namun dapat mendorong peningkatan nilai perusahaan tersebut melalui peningkatan kinerja keuangan, H8 ditolak, karena 
secara simultan Value Added Intellectual Capital bernilai negatif dan tidak signifikan terhadap nilai perusahaan (Tobin's Q) jika diuji secara langsung dan namun bernilai positif serta signifikan terhadap nilai perusahaan melalui mediator kinerja keuangan yang artinya setiap peningkatan nilai tambah yang dihasilkan oleh elemen-elemen intellectual capital tidak akan mendorong peningkatan nilai perusahaan secara langsung dan namun dapat mendorong peningkatan nilai perusahaan tersebut melalui peningkatan kinerja keuangan, H9 diterima, karena jika dilihat dari hasil uji mediasi yang positif dan signifikan terhadap nilai perusahaan dapat diketahui bahwa peningkatan kinerja keuangan (ROA, ROE, dan GR) akan mempengaruhi kenaikan nilai perusahaan (Tobin's Q) dan selain itu kinerja keuangan juga dapat memediasi pengaruh setiap elemen-elemen intellectual capital (VAHU, STVA, dan VACA) baik secara parsial maupun serempak terhadap nilai perusahaan.

\section{REFERENSI}

Agustiana, Devy. (2020). Pengaruh Intellectual Capital Terhadap Kinerja Keuangan Dan Nilai Pasar Perusahaan. JIAT. Vol.01. DOI: 10.37476/ akmen. v16i4.793.

Brigham, Eungene F. dan Joel F. Houaton, (2001). Manajemen Keuangan, Penerbit Erlangga, Jakarta, hal. 36

Bontis, N (1998). Intellectual Capital: An exploratory Study that develop Measures and Models. Management Decisions.

Chariri, A \& Imam Ghozali (2007).Teori Akuntansi Penerbit Diponegoro, Semarang

Habiburrachman. (2008). Kajian tentang Pentingnya Intellectual Capital dalam mendukung Peningkatan Kinerja Perusahaan. Jurnal Administrasi dan Bisnis, Vol 2. No.1 Juli 2008

Hartati, H (2014). Intellectual Capital Dalam Meningkatkan Daya Saing: Sebuah Telaah Literatur. Fakultas Ekonomi Universitas Terbuka: Jurnal Etikonomi Vol.13.

Jayanti \& Binastuti. (2017). Pengaruh Intellectual Capital Terhadap Nilai Perusahaan dengan Kinerja Keuangan Sebagai Variabel Intervening Pada Perusahaan Perbankan yang Terdaftar di Bursa Efek Indonesia. Fakultas Ekonomi Universitas Gunadharma. Jawa Barat. Jurnal Ekonomi Bisnis Volume 22 No.3.

Listiadi, Agung. (2015). Pengaruh Kinerja Keuangan Terhadap Nilai Perusahaan Sebagai Manifestasi Pembelajaran Investasi. Fakultas Ekonomi UNESA. Jurnal Ekonomi dan Pendidikan. Vol. 3 No. 1 Tahun 2015.

Loi. (2019). Pengaruh Intellectual Capital Terhadap Nilai Perusahaan dan Kinerja Keuangan Sebagai Variabel Moderating Pada Perusahaan Manufaktur Yang Terdaftar Di Bursa Efek Indonesia Tahun 2012-2017. Jurnal Ekonomi dan Bisnis. Universitas Sumatera Utara.

Ozkan, Nasif, Cakan, and Kayacan. (2016). "Intellectual Capital and Financial Performance: A Study of Turkish Banking Sector. Borsa Istanbul" Review xx, 1-9

Pramelasari, Yosi. (2016). Pengaruh Intellectual Capital Terhadap Nilai Pasar dan Kinerja Keuangan Perusahaan. Semarang: Jurnal Ekonomi. Universitas Diponegoro.

Pulic. A. (1998). Measuring the Performance of Intellectual Potential in Knowledge Economy. Paper presented at the $2^{\text {nd }}$ McMaster World Congress on Measuring and Managing Intellectual Capital, Austria.

Ulum, Ihyaul. (2017). Intellectual Capital: Model Pengukuran, Framework Pengungkapan, dan Kinerja Organisasi. Malang: Penerbit Universitas Muhammadiyah Malang (UMM). 